UDC 811'42.161

DOI https://doi.org/10.32838/2663-6069/2020.2-1/24

Skrypnyk N. I.

Communal Higher Education Institution "Vinnytsia Humanities Pedagogical College"

\title{
TEXT AS THE SOURCE OF FORMING FUTURE PHILOLOGIST TEACHERS`COMMUNICATIVE AND SPEECH COMPETENCE
}

\begin{abstract}
Speech competence formation is an integral part of every specialist's training and is of particular relevance in today's economic and pedagogical context, since communication provides career opportunities and professional success. The article analyzes communicative and speech competence as a didactic problem, considers the essence of the concepts "text", "educational text", "written text", "oral text", clarifies the definition of "students "communicative and speech competence". It is determined that the text should now be considered as a universal didactic unit, which provides a comprehensive knowledge of the language, the normative use of language signs and contributes to the formation of useful communication and speech skills. The characteristics of oral text, written text, educational text, types of educational text are given on the basis of the analysis of scientific works. It is emphasized that the educational text of any textbook must meet the following requirements: logic, coherence, integrity, accessibility, scientific city, consistency, continuity, integrative knowledge. Important characteristics of the text are accuracy, logic, coherence, expressiveness, which are achieved through evidence, argumentation. The textbook should be used in the process of learning linguistic topics as it encourages students to build coherent statements. It is stressed that messages, instructions, reports, observations, public speaking, oral or written answers are means of forming the ability to build expressions in oral and written forms. Thus, text can be presented as a subject of study, as a means of learning, as a product of teaching.
\end{abstract}

Key words: communicative and speech competence, text, educational text, written and oral text, speech, communication.

Introduction. New priorities for educational competency are set out in the National Doctrine of Development of Ukrainian Education, the Law of Ukraine "About Education", the National Program "Education" (Ukraine of the 21st Century), the Decree of the President of Ukraine "About the National Strategy of Educational Development in Ukraine until 2021". Today, the modern world requires individuals who are ready to communicate effectively and think critically, professionals who are able to work in a team, set a goal and achieve it, communicate in professional broadcasting in all spheres of a democratic society. The communicative and vocational competence is particularly important in higher education institutions, which is dictated by the demands of time and is defined as one of the key competences of the modern educational process.

Scientists such as M. Bakhtin [1], I. Galperin [3], L. Loseva [11], O. Moskalskaya [14] and others, emphasize that the text itself is the basis that integrates elements of language, where all linguistic units acquire natural functions and, accordingly, the text is one of the effective types of cognitive activity for the development of communication and speech competence.
The main unit of speech activity is the text. Each text, covering a specific topic, contains specific information and is aimed at performing a specific communicational task. The importance of studying language in the course of speech activity, taking into account the processes that occur during listening and when talking about the different roles of the speaker and listener in the communication process, was drawn by a large number of scholars who represented the psychological paradigm. Yes, the idea of different understanding of words and expressions by the speaker and the listener in the communication process is found in Potebna, Steintal, Baudouin de Courtenay.

However, the attempt to study the language with communication participants has led to the creation of such a complex object of study that the ways that existed at this stage of development of the conceptual apparatus linguistics could not be adequately described. In this regard, introducing into the field of linguistics a new object of study - systemic relations in language - representatives of the systemstructural paradigm, passing to the description of the higher levels of the linguistic system, created a base for the study of a new object - text, in its statics and dynamics $[17$, c. 150$]$. 
The interest of scholars in the problems of the text is evidenced by the large number of works of Ukrainian and foreign researchers, in particular N. Harutyunova, F. Batsevich I. Bechta, I. Galperin, S. Karaman, V. Karasyk, G. Kolshansky, M. Kochergan, M. Makarov, L. Friedman, Y. Habermas, Z. Schmidt and others. Definitions of the term "text" refer to one of the controversial issues that are being discussed ambiguously, by linguists (D. Barannik, A. Koval, O. Ponomaryov, O. Selivanov, etc.), psychologists (L. Vygotsky, I. Zimnya, T. Ladyzhenskaya, O. Luria, I. Sinitsa, etc.) and lingvodidakts (O. Bilyaev, O. Goroshkina, V. Melnichiko, M. Stelmakhovich, I. Khomyak, etc.).

The object of the study is to develop the communicative and vocational competence of future vocabulary teachers in the process of working with the text. The purpose of the article is to investigate the originality of the text and to determine its role in the process of communicative speech act. According to this goal, the following tasks were defined: to clarify the definitions of the key concepts "text", "educational text" "oral text", "written text", "communicative and speech competence of students-philologists", to study the functioning of text in communication, to determine the need for text in the process of speech activity and related problems, differentiate texts by form of communication, analyze types and genres of speech.

The realization of the stated purpose and the solution of the set tasks were carried out through the use of the following methods of research: analysis, synthesis, generalization of scientific researches on the problem of formation of communicative-speaking competence of students in the process of working with the text.

Thus, the text is a complex communicative unit of the highest order, which is a prototype, product, and object of communicative-cognitive activity, and is also an effective didactic means of improving the communicative-speaking competence of future philological teachers.

Basic material. Text is an exercise of linguistic competence in the process of communicative-speaking activity. For researchers, the distinction is made between the concepts of "text", "speech", "discourse", which are extremely important for understanding the term "text". In the early 70's of XX century. an attempt was made to differentiate the concepts of "text" and "discourse" by including the category of situation. Discourse was interpreted as "text plus situation" and text accordingly - as "discourse minus situation". The text is a phenomenon narrower than discourse and has features of a closed system, as well as a written and oral form of embodiment.

Note that broadcasting arises because of the need for communication. It is always aimed at the listener and intended to communicate with him. Basic in the speech development of language learners is the improvement of the ability to use speech as a means of communication. I. Shevchenko and O. Morozova under the speech understand speech activity, which takes place in a broad socio-cultural context, is a set of process and result, characterized by continuity and dialogism [5].

According to T. Ladyzhenskaya, the set of conditions that determine broadcasting, constitute a communication situation [10, c. 89]. The speech situation is an important component in the communication process, as it not only stimulates expression, but also plans its form, style, type and genre, creates certain conditions for communication.

Speech competence is a basic indicator of the professional competence of the modern specialist in philological profile, and therefore can not be applied only to a particular academic discipline, and should cover the entire range of proposed subjects, which is provided for by the appropriate educational and professional training program for future teachers. According to L. Mamchur, "An important factor in the formation of the speech competence of a future teacher-philologist is his speech development, which involves mastering the system of speech knowledge and skills required for communication in different types of speech activity. An indicator of this development is communicative competence, that is, the ability to communicate, which leads to the active use of language, the ability to perceive and reproduce the content of another's language, to produce their own, demonstrating their intellectual development, cultural achievements and values" [13].

The perception of text is a much more complex process than the perception of a communicative act: the content of the whole text is modulated by the interpretation of certain communicative acts. The perception of the text includes the reception of elements of language that the person hears or sees, establishing their relationship and forming an idea of their meaning [2, c. 103].

In the «Linguistic Encyclopedic Dictionary» the following interpretation of the definition is proposed: "Text (from Latin textus - fabric, plexus, connection) - a sequence of semantic units united by a semantic connection, whose main properties are coherence and purpose" [12].

According to I. Halperin, the text is "a work of speech-creative process, characterized by 
completeness, objectified in the form of a written document, literarily processed, consisting of a name (title) and a number of special units (transphrasal unities), combined different types of lexical, grammatical, logical, stylistic communication, which has a definite purpose and pragmatic attitude" [3, c. 45].

The basis of our exploration is the definition found in the studies of I. Kovalik, L. Matsko, M. Ivy, who define the text as "a written or oral flow, which is a sequence of sound, graphemic elements in syntactic structures (sentences), which express a complex of related judgments" [8, c. 7]; A. Selivanova is of the same opinion, understanding the text as a verbal mediator of communication, for which he is a "holistic sign form of broadcasting organization" $[15$, c. 7$]$.

It is now a clear fact that increased attention to the text, its comprehension and production occurs in the communication process. In our opinion, the text should be regarded as both the basic unit of speech, and as an expression, and as a product of speech, as well as as a completed speech work, which is characterized by informativeness, integrity, thematic unity, has its own structure, means of "coherent" parts.

You can take into account that you use the up-todate content and navigation when using this time, as well as being the source of all my units, categories, and browse the working vocabulary. For example, G. Sommer, under the term "educational text", creates a text that exists for medium purposes. At the time when it was lost that killing the main criterion was to play a didactic criterion, not a linguistic one. The main didactic criterion of the educational text G. Sommer sees in its function, which is used in the generation of new oral or written texts [7].

An important tool for developing language skills in the educational process, as well as a source for learning language units, is a textbook. For example, G. Sommer claims it an "educational text" as used for educational purposes. The scientist points out that the didactic criterion should play the main criterion, not the linguistic one. The main didactic criterion of the educational text G. Sommer considers its function, which is manifested in the generation of new oral or written texts [7].

Thus, T. Kudryavtseva proposes to consider educational texts as an object of learning and as a means of learning. The scientist states: "Types of educational text as an object of learning are differentiated from the content side by means of construction; and types of educational text as a means of learning differing in formal characteristics" [9, c. 40]. N. Goncharova divides the educational texts into descriptions and stories, reflections and proofs, arguing that "since any content is expressed in a particular expression, the text, the logical structure of each particular text will be determined by the logical structure of the type of content" [4, c. 230].

Summarizing everything, we can conclude that the educational text as a means of forming communicative, linguistic, speech and socio-cultural competence is endowed with rich didactic potential. In context of the globalization process, which has covered all aspects of social life and the sphere of education, the educational text should be focused on solving a specific didactic task in different situations of the educational process, on the formation of key and subject competences in students.

At the heart of the formation of communicativespeaking competence of future Ukrainian language teachers, the key is undoubtedly the oral and written text. In the linguistic education the text is referred to as "a segment of speech or expression (oral and written) relating to a specific field. In the process of performing a certain task, it becomes an act of speech activity and can be both a support and a goal, both a product and a process" [2, c. 10]. According to M. Vashulenko, I. Hudzik, T. Donchenko, I. Zimnya, V. Melnichiko, M. Pentylyuk, I. Khomyak, O. Khoroshkovskaya, the text is a universal product for the development of productive and receptive types of speech activity.

In the process of listening, it becomes important to be able to perceive utterances (phonetic skills), to identify the language of the message (linguistic skills), to understand the messages (semantic skills), to interpret the messages (cognitive skills). When reading, it is first and foremost about the ability to perceive written text (technical reading skills), to identify messages (language skills), to understand messages (semantic skills) [2].

Oral text is text created verbally. Written text is created or recorded in writing. These types of texts are not only a means of language learning, but also an object of assessment. In particular, in the speech test, oral text is evaluated as a result of speech according to the following parameters: "discursive organization, interaction, pronunciation, grammar and vocabulary" $[18$, c. 81$]$. Written text in the assessment of productive skills - writing is assessed by the criteria "content, communicative achievements, structure, language (vocabulary and grammar)" [18, c. 32$]$.

We believe that text itself is an important means of assimilating new material and at the same time an indicator of learning outcomes based on texts authored 
by future philologists in accordance with educational and professional programs. It should also be remembered that the text is a coherent statement that consists of a group of sentences united by the theme and the main purpose, as well as the author's attitude to what is being communicated. There are three logical parts to the text: the beginning, the main part, and the ending.

Nina Stankevich interprets the text as the basis of any kind of speech activity: dialogue, audiotext, text for reading, written work. In her opinion, in the analysis of types of speech activity educational texts can be classified in various ways [16, c. 43]. We propose to classify the types of educational texts by the following criteria: the content and method of presentation of the material - text-story (oral or written text: article, work, translation, letter, message), text-description (genres: landscape, portraiture, characteristics of people, phenomena), text-reasoning (reflection-statement, reflectionobservation, reflection with evidence); by the nature of psychological and emotional influence on the participants of the educational process - textillustration (drawing), text-scheme, text-symbol; by results of educational interaction - text-algorithm, text-instruction, text-test. In the process of working on these types of texts, students of philology are formed appropriate communication and speaking skills, skills, social experience, spiritual values.

It is the text as didactic material that represents coherent speech, interpersonal communication, promotes the acquisition of national and universal cultural and spiritual values, expression of speech, norms governing relations between people.

Conclusions. As a result, it can be stated that the didactic text material should be informative and appropriately selected, to meet the needs of nowadays. The greatest element in the structure of the text is the complete speech communication, the conversation that correlates in speech with the macro or microtext. Oral and written texts function through speech events.

Prospects are seen in the development and scientific substantiation of ways of introduction of professionally oriented texts, which traditionally are divided into dialogue (dialogical text), monologue (monologic text), polylogist.

\section{References:}

1. Bakhtin M. M. (1986) Problemy rechevykh zhanrov. Literaturno-kriticheskie stati [Problems of speech genres. Literary-critical articles]. Moscow : Hudozhestvennaya literatura. (in Russian).

2. Belyanin V. P. (2003) Pisholingvistika: uchebnik [Pischolinguistics: a textbook]. Moscow: Moskovskiy psihologo-sotsialnyiy institut. (in Russian).

3. Galperin I. R. (2004) Tekst kak ob"ekt lingvisticheskogo issledovaniya [Text as an object of linguistic research]. Moscow : Editorial URSS. (in Russian).

4. Goncharova N. (1998) Strukturnye osobennosti uchebnykh tekstov distsiplin lingvisticheskogo tsikla [Structural features of educational texts of disciplines of the linguistic cycle]. Systema $i$ struktura skhidnoslovianskykh mov: mizhkafedralnyi zb. nauk. prats - The System and Structure of the Eastern Slavic Languages: An Interdepartmental Collection. of sciences works. Kyiv : Natsionalnyi pedahohichnyi universytet imeni M. P. Drahomanova, pp. 229-237. (in Russian).

5. Shevchenko I. S. (Eds.) (2005) Dyskurs yak kohnityvno-komunikatyvnyi fenomen: monohrafiia [Discourse as a Cognitive-Communicative Phenomenon: Monograph]. Kharkiv : Konstanta. (in Ukrainian).

6. Nikolaev S. Iu. (Eds.) (2003) Zahalnoievropeiski rekomendatsii z movnoi osvity: vyvchennia, vykladannia, otsiniuvannia [Pan-European recommendations for language education: study, teaching, assessment]. Kyiv : Lenvit. (in Ukrainian).

7. Sommer G. (1996) Tipy pismennykh uchebnykh tekstov dlya razvitiya govoreniya i pisma [Types of written educational texts for the development of speaking and writing]. Proceedings from MIIM '96: "Voprosyi lingvistiki i lingvodidaktiki. Materialyi konferentsii MAPRYAL - Issues of linguistics and linguistics methodology. MAPRYAL" (pp. 223-228). Krakow : Wydawnictwo Naukowe WSP. (in Russian).

8. Kovalyk I.I. (1984) Metodyka linhvistychnoho analizu tekstu [Methods of linguistic analysis of the text]. Kyiv : Vyshcha shkola. (in Ukrainian)/

9. Kudryavtseva T. S. (1984) Funktsionirovanie teksta $v$ uchebnom protsesse [Functioning of the text in the educational process]. Moscow : Nauka. (in Russian).

10. Ladyzhenskaya T. A. (1986) Zhivoe slovo: ustnaya rech kak sredstvo i predmet obucheniya: ucheb. posob [The Living Word: Oral Speech as a Means and Subject of Learning: Textbook]. Moscow. (in Russian)

11. Loseva L. M. (1980) Kak stroitsya tekst: posobie dlya uchiteley [How the text is constructed: a manual for teachers]. Moscow: Prosveschenie. (in Russian)

12. Yartseva V. N. (Eds.) (1990) Lingvisticheskiy entsiklopedicheskiy slovar [Linguistic Encyclopedic]. Moscow: Sov. Entsiklopediya. (in Russian) 
13. Mamchur L. (2013) Formuvannia movno-rytorychnoi kompetentnosti maibutnoho vchytelia-slovesnyka [Formation of linguistic-rhetorical competence of a future teacher-philologist]. Problemy pidhotovky suchasnoho vchytelia: zb. nauk. prats Umanskoho derzhavnoho pedahohichnoho universytetu imeni Pavla Tychyny-Problems of modern teacher preparation: Coll. of sciences. works of the Uman State Pedagogical University named by Pavel Tychyna. (Vol. 8 (Part 2)). (pp. 182-186)/ Uman : FOP Zhovtyi O. O. (in Ukrainian)

14. Moskalskaya O. I. (1981) Grammatika teksta [Grammar of the text]. Moscow : Vyisshaya shkola. (in Russian)

15. Selivanova E. A. (2004) Osnovyi lingvisticheskoy teorii teksta i kommunikatsii: monogr. ucheb. posob. [The Foundations of Linguistic Theory of Text and Communication: Monogram. Textbooks]. Kyiv : Fitosotsiotsentr. (in Russian)

16. Stankevich N. (2007) Vydy movlennievoi diialnosti v aspekti linhvodydaktyky. [Types of speech activity in the aspect of linguistics]. Teoriia i praktyka vykladannia ukrainskoi movy yak inozemnoi - Theory and Practice of Teaching Ukrainian as a Foreign Language, 2, 40-47. Lviv : Vydavn. tsentr LNU imeni Ivana Franka. (in Ukrainian)

17. Zwilling M. Ya. (1987) Obschestvenno-politicheskiy i nauchnyiy tekst kak predmet obucheniya inostrannyim yazyikam [Socio-political and scientific text as a subject of instruction in foreign languages]. Moscow: Nauka. (in Russian)

18. Handbook for teachers for exams from 2016. Cambridge English. (n.d.). base. cambridgeenglish.org. URL : fromhttps://www.cambridgeenglish.org/Images/167791-cambridge-english-first-handbook.pdf (accessed: 04/18/2020).

\section{СКРИПНИК Н. І. ТЕКСТ ЯК ФОРМУВАЛЬНА КОМУНІКАТИВНА ТА МОВЛЕННСВА КОМПЕТЕНТНІСТЬ МАЙБУТНІХ УЧИТЕЛІВ-ФІЛОЛОГІВ}

Формування мовленнєвої компетентності є невід' ємною складовою частиною навчання кожного фахівия і набуває особливої актуальності в сучасних економічних, педагогічних умовах, оскільки комунікація забезпечує можливість кар'єрного росту та професійного успіху. У статті проаналізовано комунікативно-мовленнєву компетентність як дидактичну проблему, розглянуто сутність понять «текст», «навчальний текст», «письмовий текст», «усний текст», уточнено дефініцію «комунікативно-мовленнєва компетентність студентів-словесників». Визначено, що текст нині варто розглядати як універсальну дидактичну одиницю, яка забезпечує иілісне пізнання мови, нормативність уживання мовних знаків $і$ на иій основі сприяє формуванню ужиткових комунікативно-мовленнєвих умінь і навичок. На основі проведеного аналізу наукових робіт надано характеристику усного тексту, письмового тексту, навчального тексту, типів навчального тексту. Осмислення тексту - складний процес, він будуються за логічними правилами Акиентовано увагу на тому, що навчальний текст будь-якого підручника, посібника має відповідати таким вимогам: логічність, зв 'язність, иілісність, доступність, науковість, послідовність, наступність, інтегративність знань. Важливою якістю навчального тексту є точність, логічність, зв'язність, виразність, які досягаються шляхом доказовості, аргументованості. Під час вивчення лінгвістичних тем варто використовувати навчальний текст, адже він стимулює студентів до побудови зв'язних висловлень. Визначено, якщо розглядати мовлення як мовленнєвий продукт, то до основних засобів формування у здобувачів освіти вміння будувати висловлення в усній і писемній формах мовлення будуть належати не лише перекази та твори, а також і такі засоби: повідомлення, інструкиія, відгук про твір мистеитва, науково-популярну статтю, усна відповідь на занятті, звіт про виконану роботу, виступ на засіданні гуртка, привітальна промова, лист, щоденник життя і спостережень, письмова відповідь на занятті, тези, конспект статті, роздум (міркування) на ту або іншу тему, доповідь. Отже, текст можна представити як предмет навчання (те, чому потрібно навчити), як засіб навчання (те, яким способом навчати), як продукт навчання - самостійно створені студентами-філологами тексти, і текст є результатом навчання.

Ключові слова: комунікативно-мовленнєва компетентність, текст, навчальний текст, письмовий та усний текст, мовлення, спілкування. 